\title{
Determination of cadmium and lead in human milk
}

\author{
${ }^{1 *}$ E. Rahimi; ${ }^{2}$ M. Hashemi; ${ }^{3}$ Z. Torki Baghbadorani \\ ${ }^{1}$ Department of Food Hygiene, Faculty of Veterinary Medicine, Islamic Azad University of Shahr-e Kord, \\ Shahr-e Kord, Iran \\ ${ }^{2}$ Department of Nutrition, Faculty of Health, Islamic Azad University of Shahr-e Kord, Shahr-e Kord, Iran \\ ${ }^{3}$ Hospital of Shohadae Lenjan, University of Isfahan Medical Science, Isfahan, Iran
}

Received 9August 2008; $\quad$ revised 5 June 2009; accepted 11 August 2009; available online 1 Sempember 2009

\begin{abstract}
The objectives of this study were to determine cadmium and lead concentrations in the breast milk of healthy lactating women who were living in Zarrinshahr, an industrial area of Iran and to investigate the effect of mother's age, parity and smoking habits in families living in the vicinity of areas contaminated with heavy metals. Cadmium and lead concentrations were determined by graphite furnace atomic absorption spectrometry in 44 milk samples from healthy lactating women collected on first to sixth postpartum week. Accuracy of the analysis was checked by various methods including the use of reference material. The mean \pm standard deviation of cadmium and lead concentrations in human milk were $2.44 \pm 1.47 \mu \mathrm{g} / \mathrm{L}$ (range $0.62-6.32 \mu \mathrm{g} / \mathrm{L}$ ) and $10.39 \pm 4.72 \mu \mathrm{g} / \mathrm{L}$ (range 3.18$24.67 \mu \mathrm{g} / \mathrm{L}$ ), respectively. There was a positive correlation between the concentrations of lead in milk samples and mother's age and parity $(\mathrm{P}<0.05)$. Also the concentration of cadmium in breast milk significantly increased $(\mathrm{P}<0.05)$ in mothers who were actively and/or passively exposed to smoking. The results of this study showed that lead and cadmium concentrations in milk samples from lactating women in Zarrinshahr were high. This can be a major public health hazard for the inhabitants living in this industrial region of Iran.
\end{abstract}

Keywords: Breast milk; Heavy metals; Industrial area; Pollution; Toxic trace elements

\section{INTRODUCTION}

Human milk is usually the only source of food for infants during the first four to five months of their lives. Many chemicals can be transferred from the body stores and from blood into the breast milk of a lactating mother. Despite the attention focused on environmentally persistent organochlorine compounds in human milk, levels of toxic metals in milk are also of significance (Wappelhorst et al., 2002; Koizumi et al., 2008). Each metal is distributed in a characteristic way between the milk fractions. Cadmium and lead are of considerable interest due to their toxicity and widespread use (AbdelGhani et al., 2007; Gueu et al., 2007; Samarghandi et al., 2007; Karbassi et al., 2008). In rat, lead is almost exclusively found in the casein fraction (96\%) of milk whereas cadmium is distributed mostly between fat (49 $\%$ ) and casein (43\%) fractions (Oskarsson et al., 1998).

*Corresponding Author Email: ebrahimrahimi55@yahoo.com Tel.: +98913 327 8377; Fax: +98311 6259809
The kidneys are the major targets of cadmium toxicity following oral exposure. A specific indicator of cadmium-induced renal effects is tubular proteinuria. An increase in urine cadmium correlates well with low molecular weight proteins in urine. Other effects include disturbances in calcium metabolism, hypercalciuria, formation of renal stones (Hayano et al., 1996) and hypertension during pregnancy (Kosanovic et al., 2002).

The nervous system is the principal target organ for lead, although lead can adversely affect most organs in the body. The nervous system of the fetus and young children is particularly vulnerable to lead because of its rapid growth during this time. Many studies have demonstrated neurobehavioral impairment in children even at low lead exposure levels (Rice, 1996; Tripathi et al., 1999). A decrease of IQ in children was associated with an increase in blood lead 
(Schwartz, 1994) and tooth lead (McMichael et al., 1994).

The objectives of this study were to determine cadmium and lead concentrations in the breast milk of healthy lactating women who were living in Zarrinshahr, an industrial area of Iran and to investigate the effect of mother's age, parity and smoking habits in the family on the concentration of these heavy metals.

\section{MATERIALS AND METHODS}

Human milk samples

From August 2006 to March 2007 a total of 44 milk samples were collected from 44 healthy women who were living in Zarrinshahr, Iran, at least two years before pregnancy. Zarrinshahr, located in the center of Iran, is an industrial city near a large iron foundry, a steel plant, an ordnance plant and a cement plant. The milk samples were taken during first to sixth postpartum week using a conventional breast pump at the Hygiene and Treatment Center of Zarrinshahr. All the milk samples were stored at $-18{ }^{\circ} \mathrm{C}$ in clean polyethylene containers which were previously soaked in 1:1 nitric acid for one day and well rinsed with doubly distilled water $\left(\mathrm{ddH}_{2} \mathrm{O}\right)$. The samples were grouped based on age ( $\leq 30 \mathrm{y}$ vs. $>30 \mathrm{y}$ ) and parity (primiparous vs. multiparous). Eleven milk samples were taken from lactating women who were smoking or were passively exposed to smoke from other family members during pregnancy.

\section{Determination of cadmium and lead}

A total of $25 \mathrm{~mL}$ of the milk samples were acid digested with $7 \mathrm{~mL}$ of $\mathrm{HNO}_{3}$ (Merck, Germany) and 7 $\mathrm{mL}$ of $30 \% \mathrm{H}_{2} \mathrm{O}_{2}$ (Merck, Germany) in a semi-closed glass digestion apparatus. After cooling, volume was adjusted to $50 \mathrm{~mL}$ with $\mathrm{ddH}_{2} \mathrm{O}$. The concentrations of cadmium and lead were determined by the graphite furnace atomic absorption spectrometry method using UNICAM 939 (Unicam, Cambridge, UK) apparatus with electrothermic atomizer GF-90 according to the method described previously (Ursinyova and
Masanova, 2005). The detection limits calculated as three times the standard deviation were $0.038 \mu \mathrm{g} / \mathrm{L}$ and $0.043 \mu \mathrm{g} / \mathrm{L}$ of milk for cadmium and lead, respectively. The accuracy of the analysis was checked by various methods including the use of reference material (BCR No 150). The certified and observed metal concentrations are presented in Table 1.

\section{Statistical analysis}

Using SPSS/16 statistical software; SPSS Inc., USA, a t-test analysis was performed and differences were considered significant at values of $P<0.05$. For the statistical analysis, values below the detection limit were set to half that level.

\section{RESULTS AND DISCUSSION}

The cadmium and lead concentrations in 44 human milk samples, taken on the first to sixth postpartum week in Zarrinshahr are presented in Table 2. The mean \pm standard deviation (SD) of cadmium and lead concentrations in human milk were $2.44 \pm 1.47 \mu \mathrm{g} / \mathrm{L}$ (range 0.62 - $6.32 \mu \mathrm{g} / \mathrm{L}$ ) and $10.39 \pm 4.72 \mu \mathrm{g} / \mathrm{L}$ (range 3.18-24.67 $\mu \mathrm{g} / \mathrm{L})$, respectively.

In human milk, average background concentrations of cadmium and lead are between 0.05-2 $\mu \mathrm{g} / \mathrm{L}$ and 5-20 $\mu \mathrm{g} / \mathrm{L}$, respectively, while in the heavily polluted areas they may be up to 20 times higher (Frkovic et al., 1997). In table 3, the concentrations of cadmium and lead in human milk determined in the present study were compared with those reported from other countries.

The results of cadmium concentration in milk in this study are similar to those found in Croatia (Frkovic et al., 1997), Poland (Sikorski et al., 1989) and Turkey (Turan, 2001). The results of lead concentration in milk are between the low levels found in Sweden (Palminger Hallen et al., 1995), Australia (Gulson et al., 2001), China (Li et al., 2000) and Austria (Gundacker et al., 2000) and high levels found in Italy (Guidi et al., 1992), Mexico (Namihiria et al., 1993) and Singapore(Ong et al., 1985). The differences found between different studies conducted in different countries might also be due to different assays employed.

Table 1: Cd and $\mathrm{Pb}$ concentration in standard reference material (BCR 150)

\begin{tabular}{llll}
\hline Element & Units & & Concentration \\
\hline & & Expected result & Observed result \\
$\mathrm{Cd}$ & $\mathrm{mg} / \mathrm{g}$ & 0.218 & $0.209(0.198-0.221)$ \\
$\mathrm{Pb}$ & $\mathrm{mg} / \mathrm{g}$ & 1.0 & $1.16(0.98-1.23)$ \\
\hline
\end{tabular}


Int. J. Environ. Sci. Tech., 6 (4), 671-676, Autumn 2009

Table 2: $\mathrm{Pb}$ and $\mathrm{Cd}$ concentrations $(\mu \mathrm{g} / \mathrm{L})$ in milk from healthy lactating women from Zarrinshahr, Iran

\begin{tabular}{|c|c|c|c|c|c|}
\hline & & $\mathrm{Cd}$ & & $\mathrm{Pb}$ & \\
\hline & No. & Mean $\pm \mathrm{SD}^{*}$ (range) & $P$ value & Mean \pm SD (range) & $P$ value \\
\hline \multicolumn{6}{|c|}{ (1) } \\
\hline \multirow{2}{*}{$\begin{array}{l}<30 y \\
\geq 30 y\end{array}$} & 22 & $2.02 \pm 1.09(0.86-4.62)$ & \multirow[b]{2}{*}{0.059} & $8.92 \pm 3.28$ (3.18-14.27) & \multirow[b]{2}{*}{0.38} \\
\hline & 22 & $2.85 \pm 1.69(0.62-6.32)$ & & $11.86 \pm 5.51(4.70-24.67)$ & \\
\hline \multicolumn{6}{|l|}{ Parity } \\
\hline \multirow{2}{*}{$\begin{array}{l}\text { Primiparous } \\
\text { Multiparous }\end{array}$} & 22 & $2.06 \pm 1.26(0.62-4.62)$ & \multirow[b]{2}{*}{0.089} & $8.71 \pm 4.11(3.18-19.88)$ & \multirow[b]{2}{*}{0.016} \\
\hline & 22 & $2.81 \pm 1.59(0.76-6.32)$ & & $12.07 \pm 4.78(4.67-19.88)$ & \\
\hline \multicolumn{6}{|c|}{ Smoking habits } \\
\hline \multirow{2}{*}{$\begin{array}{l}\text { Smokers } \\
\text { Nonsmokers }\end{array}$} & 11 & $3.39 \pm 1.70(0.76-5.94)$ & \multirow[b]{2}{*}{0.011} & $12.22 \pm 5.70(5.78-24.67)$ & \multirow[b]{2}{*}{0.140} \\
\hline & 33 & $2.12 \pm 1.25(0.62-6.32)$ & & $9.78 \pm 4.28(3.18-21.08)$ & \\
\hline Total & 44 & $2.44 \pm 1.47(0.62-6.32)$ & & $10.39 \pm 4.72(3.18-24.67)$ & \\
\hline
\end{tabular}

*SD: Standard deviation

Table 3: $\mathrm{Cd}$ and $\mathrm{Pb}$ concentrations in human milk reported internationally

\begin{tabular}{|c|c|c|c|c|}
\hline Country & No. & $\mathrm{Cd}(\mu \mathrm{g} / \mathrm{L})$ & $\mathrm{Pb}(\mu \mathrm{g} / \mathrm{L})$ & Reference \\
\hline Australia & 15 & - & $0.55^{\mathrm{a}}$ & Gulson et al., 2001 \\
\hline \multirow{2}{*}{ Austria } & 51 & - & $35.8 \pm 15.0$ & Plockinger et al., 1993 \\
\hline & 23 & - & $1.5 \pm 2.6$ & Gundacker et al., 2000 \\
\hline \multirow{2}{*}{ China } & 165 & - & $4.74^{\mathrm{d}}$ & Li et al., 2000 \\
\hline & 21 & - & $52.7^{\mathrm{e}}$ & Li et al., 2000 \\
\hline Croatia & 29 & $2.54 \pm 2.52^{\mathrm{a}}$ & $7.3 \pm 8.3$ & Frkovic et al., 1997 \\
\hline Egypt & 120 & - & $30.6^{f}$ & Saleh et al., 1996 \\
\hline England & 39 & - & $30^{f}$ & Richmond et al., 1993 \\
\hline \multirow{2}{*}{ Germany } & 10 & $17.3 \pm 4.9^{\mathrm{a}, \mathrm{g}}$ & $9.1 \pm 2.5^{\mathrm{b}, \mathrm{g}}$ & $\begin{array}{l}\text { Sternowsky and Wessolowski, } \\
1985\end{array}$ \\
\hline & 10 & $24.6 \pm 7.3^{\mathrm{a}, \mathrm{h}}$ & $13.3 \pm 5.5^{\mathrm{h}}$ & $\begin{array}{l}\text { Sternowsky and Wessolowski, } \\
1985\end{array}$ \\
\hline Greece & 47 & - & $20 \pm 5^{\mathrm{a}}$ & Nashashibi et al., 1999 \\
\hline \multirow{2}{*}{ Italy } & 34 & - & $45.62^{\mathrm{b}, \mathrm{g}}$ & Guidi et al., 1992 \\
\hline & 20 & - & $126.55^{\mathrm{b}, \mathrm{h}}$ & Guidi et al., 1992 \\
\hline \multirow{2}{*}{ Japan } & 22 & - & $27^{\mathrm{b}}$ & Ding et al., 1993 \\
\hline & 68 & $0.277 \pm 1.82^{\mathrm{a}}$ & - & Honda et al., 2003 \\
\hline Malaysia & 91 & - & $21.1^{\mathrm{b}, \mathrm{g}}$ & Huat et al., 1983 \\
\hline \multirow{2}{*}{ Mexico } & 35 & - & $61.8^{\mathrm{b}, \mathrm{d}}$ & Namihira et al., 1993 \\
\hline & 33 & $0.62 \pm 0.28^{\mathrm{a}}$ & - & Rydzewska and Krol, 1996 \\
\hline \multirow[t]{2}{*}{ Poland } & 110 & $2^{\mathrm{b}}$ & - & Sikorski et al., 1989 \\
\hline & 5 & - & $6.5 \pm 2.2^{\mathrm{a}}$ & Younes et al., 1995 \\
\hline \multirow{3}{*}{ Saudi Arabia } & 31 & - & $8.9 \pm 5.3^{\mathrm{a}}$ & Younes et al., 1995 \\
\hline & 11 & - & $6.3 \pm 3.8^{\mathrm{a}}$ & Younes et al., 1995 \\
\hline & 168 & $1.73^{\mathrm{b}}$ & $31.67^{\mathrm{b}}$ & Al-Saleh et al., 2003 \\
\hline Singapore & 114 & - & $47.7^{\mathrm{b}}$ & Ong et al., 1985 \\
\hline Slovakia & 158 & $0.43 \pm 0.27^{\mathrm{a}}$ & $4.7 \pm 4.1^{\mathrm{a}}$ & $\begin{array}{l}\text { Ursinyova and Masanoua, } \\
2005\end{array}$ \\
\hline \multirow{2}{*}{ Sweden } & 39 & $0.05 \pm 0.04^{\mathrm{a}, \mathrm{d}}$ & $0.9 \pm 0.4^{\mathrm{a}, \mathrm{d}}$ & Palminger Hallen et al., 1995 \\
\hline & 35 & $0.07 \pm 0.04^{\mathrm{a}, \mathrm{c}}$ & $0.5 \pm 0.3^{\mathrm{a}, \mathrm{c}}$ & Palminger Hallen et al., 1995 \\
\hline Turkey & 30 & $2.8^{\mathrm{b}}$ & $14.6^{\mathrm{b}}$ & Turan et al., 2001 \\
\hline Iran & 44 & $2.44 \pm 1.47^{\mathrm{a}}$ & $10.39 \pm 4.72^{\mathrm{a}}$ & This study \\
\hline
\end{tabular}

a: Mean \pm SD; b: mean; c: control area; d: smelter area; e: occupationally exposed to lead; g: rural; h: urban 
The results of t-test analysis for group comparison regarding mother's age, parity and smoking habits in family and relation to cadmium and lead concentrations in milk are presented in Table 2. In the present study, mean concentration of cadmium and lead in women age $\leq 30 \mathrm{y}$ was lower than women aged $>30 \mathrm{y}$. This difference is statically significant for lead $(P<0.05)$ but not for cadmium $(P>0.05)$. Younes et al., (1995) reported that the lead concentration was significantly lower in milk samples obtained from mothers aged $\leq 20$ years $(5.1 \pm 1.4 \mu \mathrm{g} / \mathrm{L})$ compared to mothers aged $\geq 36$ years $(13.43 .5 \mu \mathrm{g} / \mathrm{L})$. On the contrary, Frkovic, et al. (1997) and Ursinyova and Masanova (2005) observed higher cadmium and lead concentrations in the milk obtained from younger mothers. However, the differences were not statistically significant. Drasch et al., (1998) and Sikorski et al., (1989) did not find mother's age effective on concentration of cadmium in milk.

In this study, 22 women were primiparous and had somewhat lower concentration of cadmium and lead in breast milk compared to women with two or more deliveries. The difference was significant for lead ( $P$ $\leq 0.05$ ) but not for cadmium. Other studies also showed no influence of parity on cadmium concentration in milk and a slight increase of lead concentration in milk from lactating multiparous women (Sikorski et al., 1989; Frkovic et al., 1997; Ursinyova and Masanova, 2005).

Smoking habits in the family (smoking during pregnancy and/or being exposed to smoke from other family members) increased cadmium concentration in milk $(P<0.05)$. A tendency toward higher cadmium concentration in smokers was observed also in the Swedish and Creation lactating women (Plaminger Hallen et al., 1995; Frkovic et al., 1997) Eynon et al., (1985) estimated that the infants of smoking mothers were exposed 20 - $40 \%$ more to cadmium than the infants from non-smoking mothers and the concentration of cadmium in milk were increased by $8 \%, 17 \%$ and $28 \%$ due to the mother's smoking habits before pregnancy; father's smoking habits and smoking at home, respectively. Leotsinidis et al., (2005) and Ursinyova and Masanova (2005) observed higher cadmium concentration in the milk in women from families with smoking habits, but differences were not statistically significant.
The results of this study show that smoking habits do not have a significant influence on the lead concentration in breast milk $(P>0.05)$ which is in accordance with the results obtained in Sweden, Croatia, Greece and Slovakia (Palminger Hallen et al., 1995; Frokvic et al., 1997; Ursinyova and Masanova, 2005). However, Gundacker et al. (2000) found that smoking increased lead concentration in milk significantly.

\section{CONCLUSION}

The results of this study show that the cadmium and lead concentration in milk samples obtained from healthy women in Zarrinshahr are high which a major public health hazard is for inhabitants of industrial locations especially neonatal and children. Cadmium and lead in milk are better absorbed into the body than other dietary components, therefore high cadmium and lead concentration in breast milk is the first source of poisoning with these heavy metals in neonates (Frkovic et al., 1997). In view of all potential consequences of advanced lead and cadmium intoxication, it is necessary to point out the importance of an early diagnosis before morphological changes have been developed. Moreover, the results of the present study indicate a need for establishing safe intake values of heavy metals in human milk.

\section{ACKNOWLEGEMENTS}

The authors wish to thank Mr. Ahmadi and Ms. Ebadati for their sincere help in performing technical parts of the project. The authors are also grateful to Ms. Zamani and Ms. Salimian for assistance in sampling.

\section{REFERENCES}

Abdel-Ghani, N.T.; Hefny, M.; El-Chagbaby G.A.F. (2007). Removal of lead from aqueous solution using low cost abundantly available adsorbents. Int. J. Environ. Sci. Tech. 4 (1): $67-73$ (7 pages).

Al-Saleh, I.; Shinwari, N.; Mashhour, A., (2003). Heavy metal concentrations in the breast milk of Saudi women. Biol. Trace Elem. Res., 96 (1-3), 21-37 (17 pages).

Ding, H. C.; Lui, H. J.; Sheu, Y. L.; Chang, T. C., (1993). Survey of Beta-Lactum antibiotics and heavy metals in infant milk powder and human milk. J. Food Drug Anal., 1 (3), 265-271 (7 pages).

Drasch, G.; Aigner, S.; Roider, G.; Staiger, F.; Lipowsky, G., (1998). Mercury in human colostrums and early breast milk. Its dependence on dental amalgam and other factors. J. Trace Elem. Med. Biol., 12 (1), 23-27 (5 pages). 
Eynon, G. R.; McKenzie-Parnell, J. M.; Robinson, M. F., (1985). Cadmium in non-smoking New Zealand women immediately following child birth. Proceedings of the University of Otego Medical School, 63, 38-40.

Frkovic, A.; Kras, M.; Alebic-Juretic, A., (1997). Lead and cadmium content in human milk from the Northern Adriatic area of Croatia. Bull. Environ. Contam. Toxicol., 58 (1), 16-21 (6 pages).

Gueu, S.; Yao, B.; Adouby, K.; Ado, G. (2007). Kinetics and thermodynamics study of lead adsorption on to activated carbons from coconut and seed hull of the palm tree. Int. J. Environ. Sci. Tech. 4 (1), 11-17 (7 pages).

Guidi, B.; Ronchi, S.; Ori, E.; Varni, P. F.; Cassinadri, T.; Tripodi, A.; Borghi, A.; Mattei, F.; Demaria, F.; Galavotti, E., (1992). Lead concentrations in breast milk of women living in urban areas compared with women living in rural areas. Pediatr. Med. Chir., 14 (6), 611-616 (6 pages).

Gulson, B. L.; Mizon, K. J.; Palmer, J. M.; Patison, N.; Law, A. J.; Korsch, M. J.; Mahaffey, K. R.; Donnelly, J. B., (2001). Longitudinal study of daily intake and excretion of lead in newly born infants. Environ. Res., 85 (3), 232245 (14 pages).

Gundacker, C.; Pietschnig, B.; Wittmann, K. J.; Lischka, A., (2000). Human milk mercury (Hg) and lead $(\mathrm{Pb})$ levels in Vienna. Adv. Exp. Med. Biol., 478, 387-388 (1 page).

Hayano, M.; Nogawa, K.; Kido, T.; Kobayashi, E.; Honda, R.; Turitani, I., (1996). Dose-response relationship between urinary cadmium concentration and $ß 2-$ microglobulinuria using logistic regression analysis. Arch. Environ. Health, 51 (2), 162-168 (7 pages).

Honda, R.; Tenji, K.; Nishijo, M.; Nakagawa, H.; Tanebe, K.; Sito, S., (2003). Cadmium exposure and trace elements in human breast milk. Toxicology, 186 (3), 255-259 (5 pages).

Huat, L. H.; Zakariya, D.; Eng, K. H., (1983). Lead concentrations in breast milk of Malaysian urban and rural mothers. Arch. Environ. Health, 38 (4), 205-209 (5 pages).

Karbassi, A. R.; Nouri, J.; Mehrdadi, N., Ayaz, G. O., (2008). Flocculation of heavy metals during mixing of freshwater with Caspian Sea water. Environ. Geo., 53 (8), 1811-1816 (7 pages).

Koizumi, N.; Murata, K.; Hayashi, C.; Nishio, H.; Goji, J., (2008). High cadmium accumulation among humans and primates: comparison across mammalian species-A study from Japan. Biol. Trace Elem. Res., 121 (3), 205-214 (10 pages).

Kosanovic, M.; Jokanovic, M.; Jevremovic, M.; Dobric, S.; Bokonjic, D., (2002). Maternal and fetal cadmium and selenium status in normotensive and hypertensive pregnancy. Biol. Trace Elem. Res., 89 (2), 97-103 ( 7 pages).

Leotsinidis, M.; Alexopoulos, A. ; Kostopoulou-Farri, E., (2005). Toxic and essential trace elements in human milk from Greek lactating women: Association with dietary habits and other factors. Chemosphere, 61 (2), 238-247 (10 pages).

Li, P. J.; Sheng, Y. Z.; Wang, Q. Y.; Gu, L. Y.; Wang, Y. L., (2000). Transfer of lead via placenta and breast milk in human. Biomed. Environ. Sci., 13 (2), 85-89 (5 pages).
McMichael, A. J.; Baghurst, P. A.; Vimpani, G. V.; Wigg, N. R.; Robertson, E. F.; Tong, S., (1994). Tooth lead levels and IQ in school-age children: The Port Pirie cohort study. Am. J. Epidem., $140 \quad$ (6), 489-499 (11 pages).

Namihira, D.; Saldivar, L.; Pustilnik, N.; Carreon, G. J.; Salinas, M. E., (1993). Lead in human blood and milk from nursing women living near a smelter in Mexico City. J. Toxicol. Environ. Health, 38 (3), 225-232 (8 pages).

Nashashibi, N.; Cardamakis, E.; Bolbos, G.; Tzingounis, V., (1999). Investigation of kinetic of lead during pregnancy and lactation. Gynecol. Obstet. Inves., 48 (3), 158-162 (5 pages).

Ong, C. N.; Phoon, W. O.; Law, H. Y.; Tye, C. Y.; Lim, H. H., (1985). Concentrations of lead in maternal blood, cord blood, and breast milk. Arch. Dis. Child., 60 (8), 756-759 (4 pages).

Oskarsson, A.; Palminger-Hallen, I.; Sundberg, J.; Grawe, K. P., (1998). Risk assessment in relation to neonatal metal exposure. Analyst, 123 (1), 19-23 (5 pages).

Palminger Hallen, I.; Jorhem, L.; Lagerkvist, B. J.; Oskarson, A., (1995). Lead and cadmium levels in human milk and blood. Sci. Total Environ., 166 (1-3), 149-155 (7pages).

Plockinger, B.; Dadak, C.; Meisinger, V., (1993). Lead, mercury and cadmium in newborn infants and their mothers. Z. Geburtshilfe Perinatol., 197 (2), 104-107 (4 pages).

Rice, D. C., (1996). Behavioral effects of lead: Commonalities between experimental and epidemiologic data. Environ. Health Perspect., 104 (2), 337-351 (15 pages).

Richmond, J.; Strehlow, C. D.; Chalkley, S. R., (1993). Dietary intake of $\mathrm{Al}, \mathrm{Ca}, \mathrm{Cu}, \mathrm{Fe}, \mathrm{Pb}$, and $\mathrm{Zn}$ in infants. Br. J. Biomed. Sci., 50 (3), 178-186 (9 pages).

Rydzewska, A.; Krol, I., (1996). Content of zinc, copper and cadmium in milk in mild of women living in Poznan. Ginekol. Pol., 67 (3), 125-128 (4 pages).

Saleh, M. A.; Ragab, A. A.; Jones, J.; El-Sebae, A. K., (1996). Regional distribution of lead in human milk from Egypt. Chemosphere, 32 (9), 1859-1867 (9 pages).

Samarghandi, M. R.; Nouri, J.; Mesdaghinia, A. R.; Mahvi, A. H.; Nasseri, S.; Vaezi, F., (2007). Efficiency removal of phenol, lead and cadmium by means of $\mathrm{UV} / \mathrm{TiO}_{2} / \mathrm{H}_{2} \mathrm{O}_{2}$ processes. Int. J. Environ. Sci. Tech., 4 (1), 19-25 (7 pages).

Schwartz, J., (1994). Low-levels lead exposure and children's IQ: A meta analysis and search for a threshold. Environ. Res., 65 (1), $42-55$ (14 pages).

Sikorski, R.; Paszkowski, T.; Radomanski, Jr. T.; Szkoda, J., (1989). Cadmium contamination of early human milk. Gynecol. Obster. Inves., 27 (2), 91-93 (3 pages).

Sternowsky, H. J.; Wessolowski, R., (1985). Lead and cadmium in breast milk. Higher levels in urban vs rural mothers during the first 3 months of lactation. Arch. Toxicol., 57 (1), 41-45 (5 pages).

Tripathi, R. M.; Raghunath, R.; Sastry, V. N.; Krishnamooethy, T. M., (1999). Daily intake of heavy metals by infants through milk products. Sci. Total 


\section{E. Rahimi et al.}

Environ., 227 (2-3), 229-235 (7 pages).

Turan, S.; Saygi, S.; Kilic, Z.; Acar, O., (2001). Determination of heavy metal contents in human colostrums samples by electrothermal atomic absorption spectrophotometry. J. Trop. Pediatr., 47 (2), 81-85 (5 pages).

Ursinyova, M.; Masanova, V., (2005). Cadmium, lead and mercury in human milk from Slovakia. Food Addit. Contam., 22 (6), 579-589 (11 pages).
Wappelhorst, O.; Kühn, I.; Heidenreich, H.; Markert, B., (2002). Transfer of selected elements from food into human milk. Nutrition, 18 (4), 316-322 (7 pages).

Younes, B.; Al-Meshari, A. A.; Al-Hakeem, A.; Al-Saleh, S.; Al-Zamel, F.; Al-Shammari, F.; Alwarthan, A., (1995). Lead concentration in breast milk of nursing mothers living in Riyadh. Ann. Saudi Med., 15 (3), 249-251. (3 pages).

\section{AUTHOR (S) BIOSKETCHES}

Rahimi, E., Ph.D., Assistant professor, Department of Food Hygiene, Faculty of Veterinary Medicine, Islamic Azad University of Share Kord, Shar-e Kord, Iran. Email: ebrahimrahimi55@yahoo.com

Hashemi, M., M.Sc., Lecture, Department of Nutrition, Faculty of Health, Islamic Azad University of Shar-e Kord, Shar-e Kord, Iran. Email: shahia54@yahoo.com

Torki Baghbadorani, Z., R.D., Nutritionist, Hospital of Shohadae Lenjan, University of Isfahan Medical Science, Isfahan, Iran. Email: zeinab.torki@gmail.com

How to cite this article: (Harvard style)

Rahimi, E.; Hashemi, M.; Torki Baghbadorani, Z., (2009). Determination of cadmium and lead in human milk. Int. J. Environ. Sci. Tech., 6 (4), 671-676. 